\title{
The so-called "beach-tower" of Kyrenia city walls, Cyprus
}

\author{
Alessandro Camiz ${ }^{a}$, Marika Griffo ${ }^{b}$, Emilia Valletta ${ }^{c}$, Almira Khafizou ${ }^{d}$ \\ ${ }^{a}$ Özyeğin Üniversitesi, Istanbul, Turkey, \\ alessandrocamiz@ozyegin.edu.tr \\ ${ }^{\text {b}}$ Dipartimento di Storia, Disegno e Restauro dell'Architettura - Sapienza Università di Roma, Rome, Italy, \\ marika.griffo@gmail.com \\ ${ }^{\mathrm{c}}$ Scuola di Specializzazione in Beni Architettonici e del Paesaggio - Sapienza Università di Roma, Rome, Italy, \\ emiliavalletta@hotmail.it \\ ${ }^{\mathrm{d}}$ Department of Interior Architecture, Girne American University, Kyrenia, Cyprus, \\ almira.khafizou@std.gau.edu.tr
}

\begin{abstract}
The so-called "beach-tower" is the smallest of the three remaining towers belonging to the Kyrenia's medieval enceinte. Semi-circular in plan, with circa $6 \mathrm{~m}$ of diameter, the tower is today partially obliterated by the medieval urban tissue and is visible only from one side. Built during the twelfth-thirteenth centuries, this harbour overlooking tower is raised on a pedestal in the north-west inner corner of the city walled enclosure. The tower shows on the outside two windows that might belong to a later phase, being too wide as defensive openings, and includes fragments of the adjoining city walls that ran to the east, towards the castle and to the west towards the beach city gate. Kyrenia city's walled defensive system was dismantled by the Venetians when the use of gunpowder cannon became prevalent, however, traces and records still remain enshrined in the medieval constructions. The paper, following the historical research, attempts to date the construction of this tower, and by examining the fortification remains with a digital survey, applies the comparison with other coeval examples together with the comparative analysis of the different masonry types.
\end{abstract}

Keywords: Fortifications, digital survey, medieval architecture, Cyprus.

\section{Historical Background}

Cerines (Kyrenia) underwent many changes through the years, experiencing rises and declines. Seeing the remains of fortifications such as towers, we are able to trace back the antecedent image of the city and its power within the Island of Cyprus. As noted by Baker, Kyrenia used to be spreading more extensively in the past (1879). There is scarce written documentation on the medieval period in Cyprus, in addition, the Venetians demolished the medieval Kyrenia fortifications in the sixteenth century and reused the materials for the enlargement of the castle. We can therefore only analyse the remaining towers to attempt a historical reconstruction of the urban enceinte. Herein we are relying on the illustrative and written forms of historical evidence to abstract the overall city portrayal and its evolution. Piri Reis drafted a map of Cyprus in 1521, which depicts Cyprus as a large island with few harbours on the northern coast. Both the map and the detailed side-text, certify the presence of "Girine Buferi", a castle with an anchorage bay and a small "Ala Kusiye" harbour on both sides. (Yilmaz, 2010). Cerines, is still appearing on Renaissance maps as a significant walled city, and in the mid-seventeenth century Mariti described it as a scarcely populated small village with an episcopal Greek church, and a Turkish mosque. 


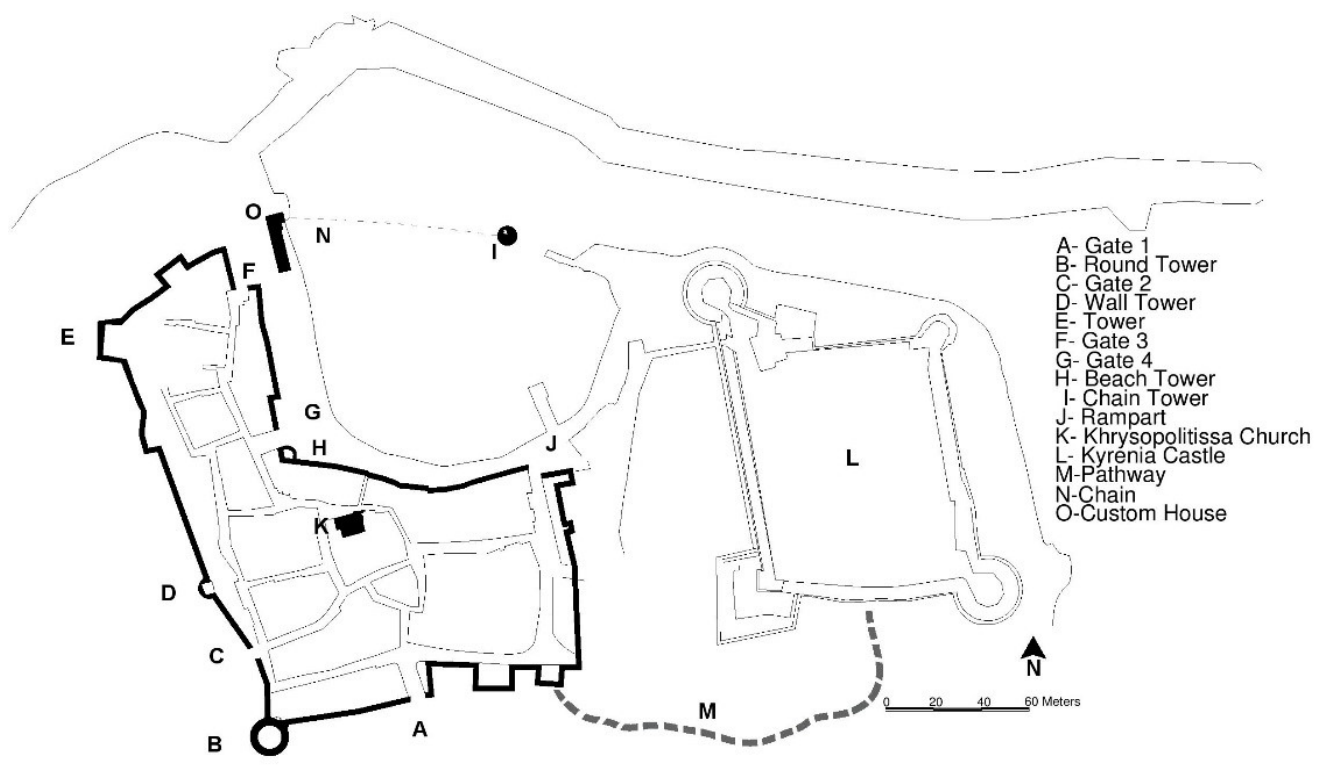

Fig. 1. Kyrenia's fortification system, plan (Baydur, 2017).

\section{The Tower}

The so-called "beach-tower" was part of the medieval walls of the city of Kyrenia, positioned to strengthen a convex node of the fortified enceinte adjacent to the harbour. The plan resulted from our survey is not complete, as the owner did not allow us to enter the inside of the structure and to visit the roof. We could not find any other survey drawing of the structure in the existing literature or in the archives of the Department of Antiquities and Museums. Provisional deteriorated wooden structures belonging to the adjoining restaurant partially cover the lower part of the tower: these constructions were of great obstacle for the survey of a site that presents to this day the semblance of a rubbish dump more than that of a monument. In our humble opinion, all the structures should be immediately removed, and the area should be cleaned for the sake of the conservation of this monument. The building requires also urgent restorations, including the replacement of the missing or damaged ashlars, removal of the plants growing everywhere, and the reparation of the roof that is probably leaking in the inside during the rainy season. The construction used the local calcarenite stone, the same material of the castle, the disappeared urban walled enclosure, the other towers, and most of the old buildings of the town of Kyrenia. These stones were brought to the site from the numerous extraction sites that are still visible in the surroundings. The cadastral plan of the tower reveals its function as clearly built on the outside of the preexisting city walls to defend the convex corner from the outside. The direction and position of the city walls are readable directly in the existing structure, as on the northern side the city walls were demolished leaving a portion visible as in a section. This corresponds with the lower wall supporting the existing urban terrace. The spatial layout is typical of the so-called système Philippien, constituted by round towers reinforcing and defending the corners of the walls. It is possible therefore to date tentatively the structure to the first half of the thirteenth century. The lower six ashlar courses of the tower follow a scarped profile, while the adjoining residual part of the city walls in the corresponding part follows a vertical section.

This difference reveals that the corner tower was clearly built in a subsequent phase. The height of 
the structure is today $8 \mathrm{~m}$. starting from the lower ground level even though it could have been taller in the past. The wall revealed some meaningful differences. We can anyhow tentatively assume the city wall fragment visible on the northern size as indication of the height of the old city walls. In this part, the city fortifications included a wall of $170 \mathrm{~cm}$ of thickness with an outside and inside revetment of calcrarenite ashlars and an inner core of rubble and cement. The analysis of the measures of the stones in the tower and in. The windows are clearly the result of a modern restoration. It is possible to recognize clearly the different surface finishing of the stones constituting the window's intrados. Furthermore, openings of such dimensions $(30 \mathrm{x}$ $150 \mathrm{~cm}$ ) cannot belong to the logic of a walled defensive system.

\section{Digital photogrammetric Survey}

In order to obtain the necessary geometrical and metric information, we surveyed the tower by using close range photogrammetric processes, together with direct survey techniques. Starting with a set of 97 digital pictures. ${ }^{1}$

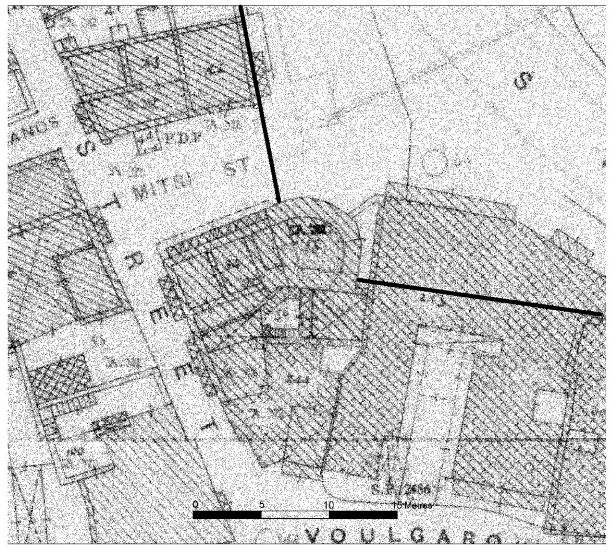

Fig. 2. Beach tower, cadastral plan, detail, in black our reconstruction of the city walls (Department of Lands and Surveys, 1918, revised 1930).

From the photographs, the software generated a 3D point cloud of 8940943 points and consequently, a texturized mesh model with 8000000 faces. We used the model to extract orthographic-images and then used a CAD software for the preparation of 2D survey drawings (plans, elevations, details) that were drafted manually in overlay with the orthographic pictures. The interpretation of the geometrical information con-

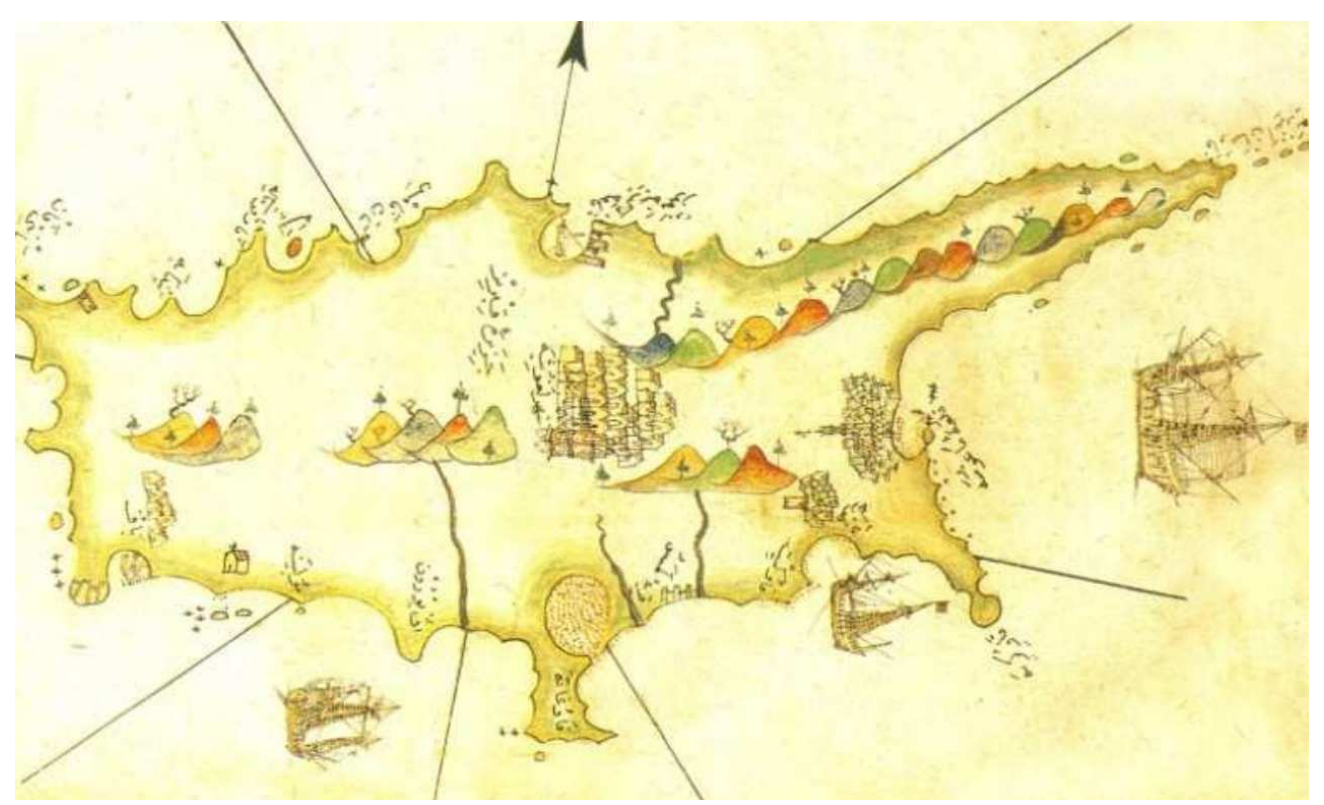

Fig. 3. The map of Cyprus by Piri Reis, 1521. (Yilmaz, 2010). 
tained within the digital 3D views generated by the software, requires indeed human critical understanding in order to achieve a proper bidimensional representation.

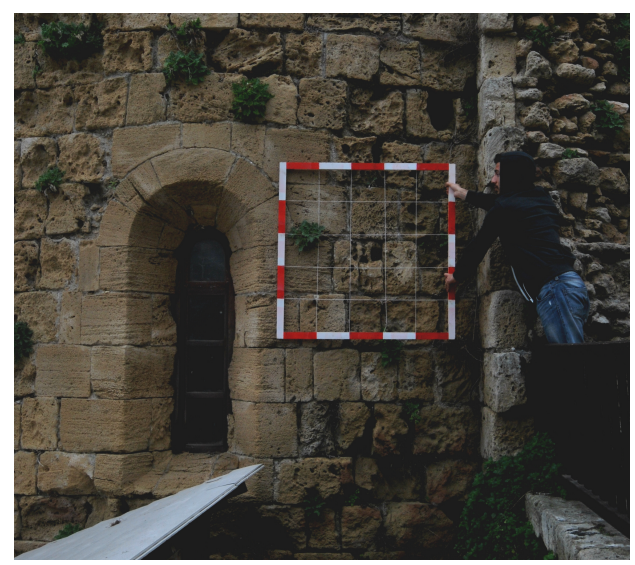

Fig. 4. Survey of the masonry type.

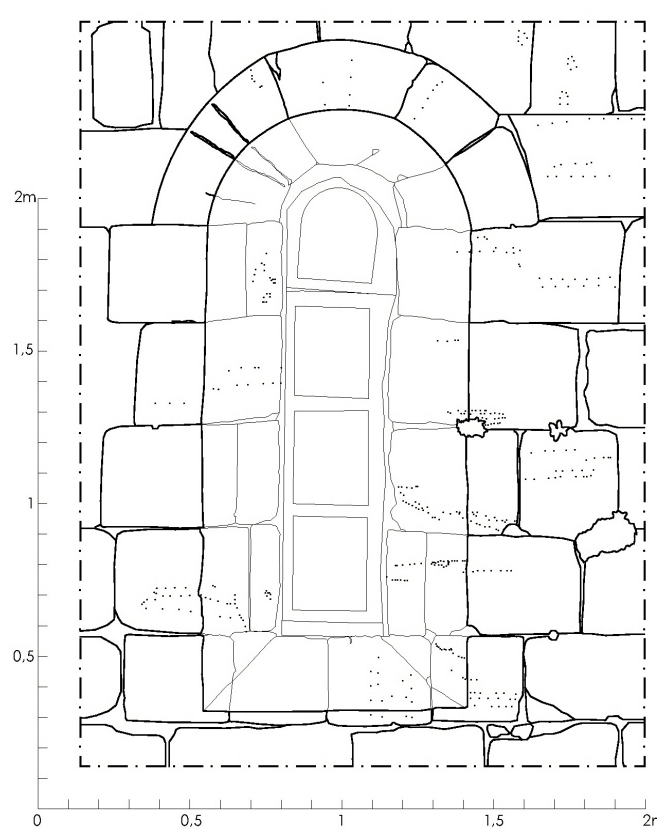

Fig. 6. Detail front elevation of the window, a modern reconstruction (Griffo, 2018).

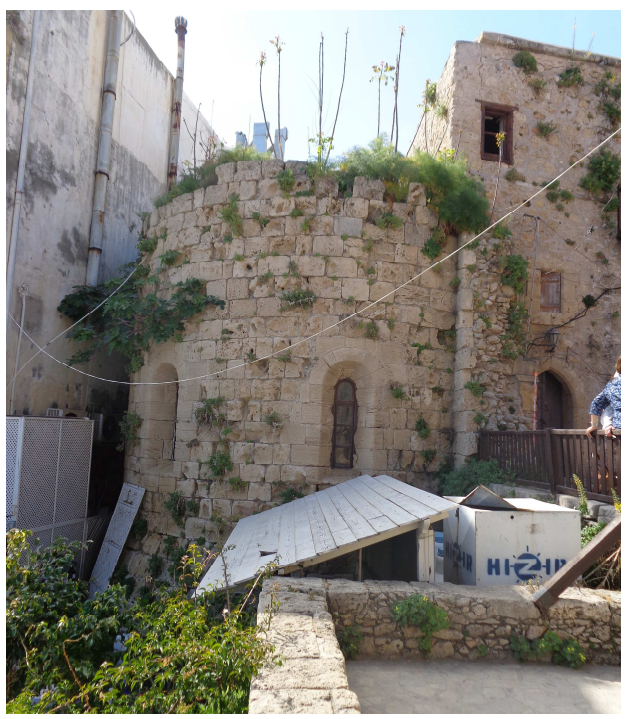

Fig. 5. The so-called beach tower, you can note the fragment of city wall on the right, and its continuation in the terrace's substructure (Camiz, 2018).

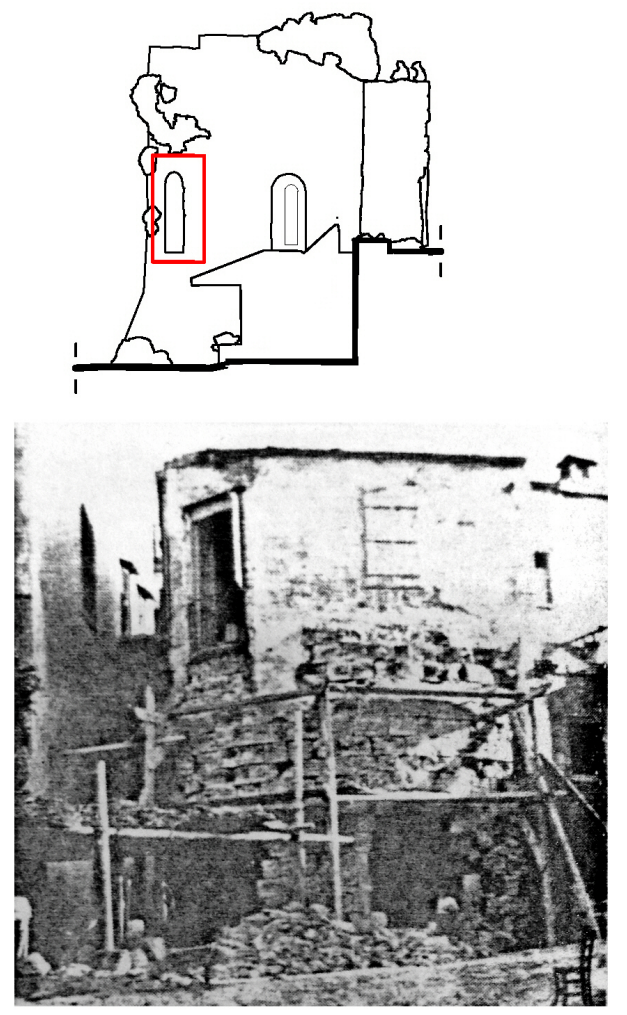

Fig. 7. The reconstruction accomplished by the Department of Antiquities (RDAC, 1935, PL). 


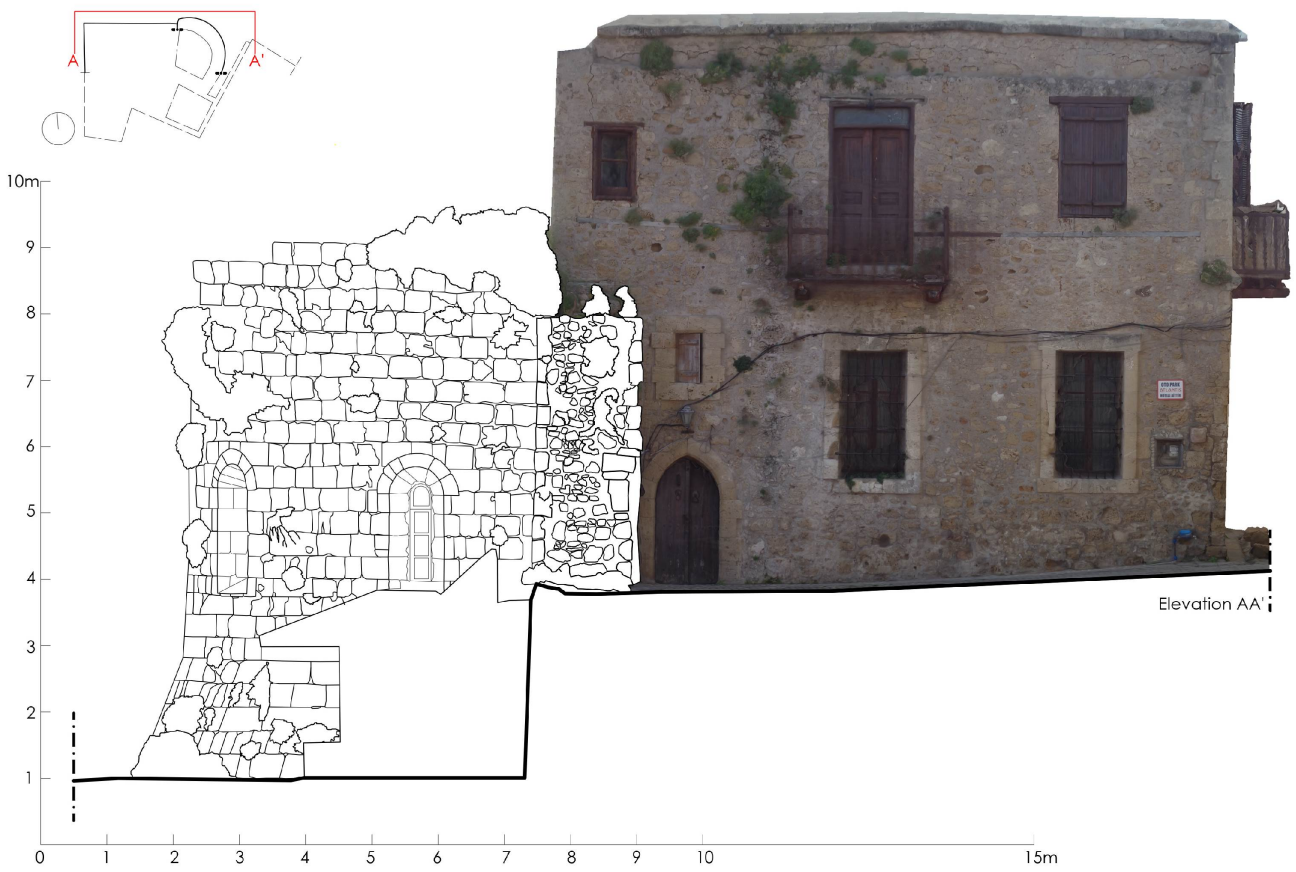

Fig. 8. Side elevation, the remains of the city walls are clearly visible (Griffo, 2018).

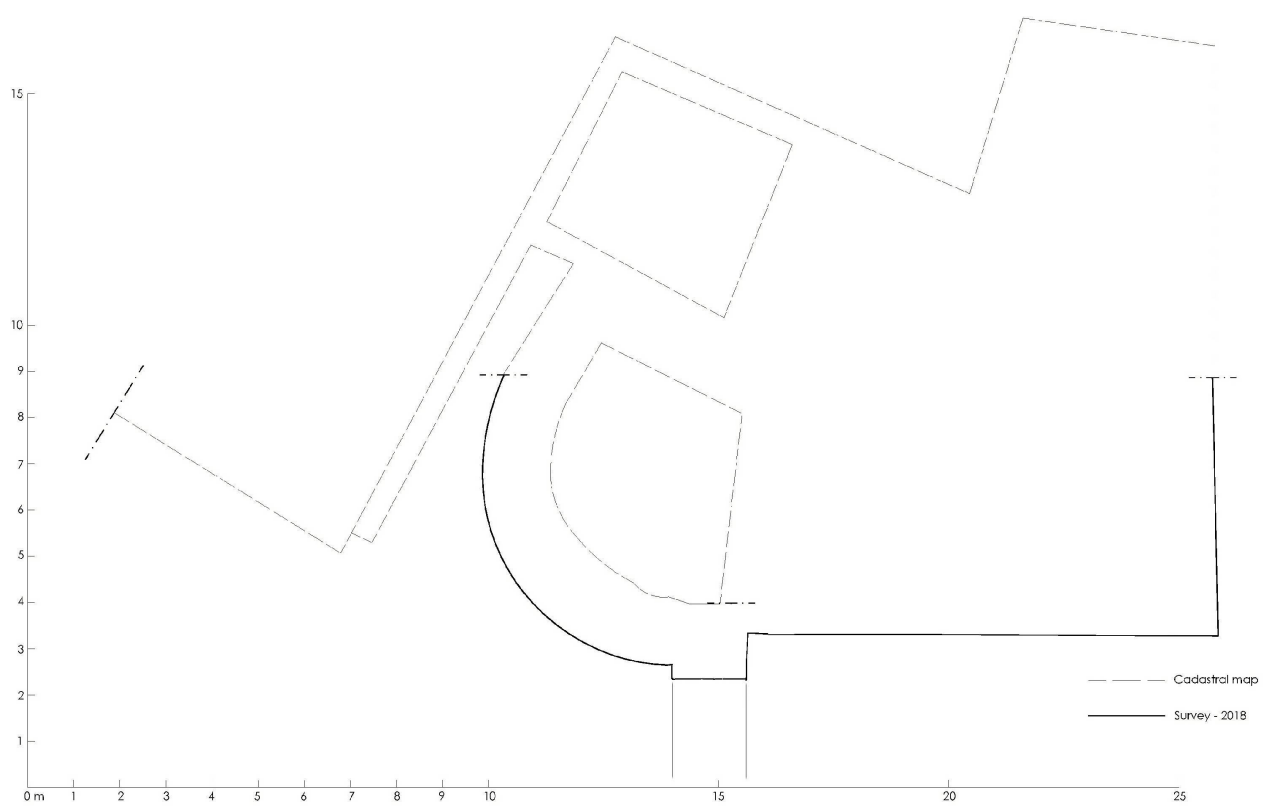

Fig. 9. Ground floor plan, the remains of the ancient city walls are clearly distinguishable, embedded within the subsequent buildings and made of calcareous ashlars of large regular size placed on isodomic plans (Griffo, 2018). 
The set of pictures and the point cloud also included the palazzetto adjacent the tower, which is therefore included in the survey. Unfortunately, it was not possible to enter the tower; the owner of the structure did not allow us to see the inside and to go on the roof. On the outside, several provisional structures in wood belonging to the restaurant partially cover the medieval structure, which we could therefore represent only in its visible parts. The result of our research is not a complete survey, but a starting point for future developments.

\section{Conclusions}

The technology of digital photogrammetry developed in recent times and since the use of digital cameras in photogrammetric applications has spread very quickly. The role of this methodology as a modern and rigorous technique of importance in the field of Cultural Heritage is undisputed today and the possibilities offered are numerous and extremely flexible, both as regards the acquisition of the data, as well as the processing procedures and final products obtainable. Flexibility is perhaps the most successful feature in this field of use, which can become complex precisely because of the enormous variety of cases and issues related to it. Moreover the acquisition of digital images, basically conceived as matrices of elements, the pixels (from picture element, i.e. image elements), whose radiometric content is expressed by the continuous function $g(i, j)$, where $i$ and $j$ are the spatial variables, have undergone a rapid evolution and a clear qualitative improvement. The radiometric content can be for example the white or black value, a grey level or an RGB value (Red Green Blue). The photogrammetric survey does not require contact with the object and can also occur with medium-low-cost rooms, factors of great importance in this sector, where sometimes the economic and temporal resources available are scarce. The new digital photogrammetric stations, powerful and fast thanks to increasingly sophisticated hardware and software components, specialised in image processing by using sophisticated calculation algorithms, with the possibility of automating many of the traditional operations related to photogrammetry, have made real time photogrammetry a reality. The so-called real-time photogrammetry happens when the time between the shooting and the production of the final result is very short.

\section{Note}

${ }^{1}$ Pictures were acquired with a compact camera (SONY DSC-W730), ISO value set at 80 , focal length: 4.5, F-stop: F/3.3 and F/8, shutter speed: variable.

\section{Bibliography}

Amadi, F. (1999). Cronaca di Cipro, Hidryma Archepiskopoy Makarioy, Leukosia.

Arkan, M.S. (2016). The urban cartography of Cyprus: between the 16 and 20th centuries, PhD Thesis, Eötvös Loránd University, Department of Cartography and Geoinformatics, Budapest.

Baker, S.W. (1879). Cyprus as I saw it in 1879, Macmillan and Co, London.

Bianchini, C.; Ippolito, A.; Bartolomei, C. (2015). The surveying and representation process applied to architecture: non-contactmethods for the documentation of Cultural Heritage, Handbook of Research on emerging Digital Tools for Architectural Surveying, Modelling and Representation, Hershey PA, Engineering Science Reference.

Borchardt, K.; Luttrell, A.; Schoffler, E. (2011). Documents concerning Cyprus from the Hospital's Rhodian archives, Cyprus Research Centre, Nicosia.

Camiz, A.; Griffo, M.; Valletta, E.; Özen, P. (2018). "The rectangular tower with machicolations of Kyrenia city walls (1191-1228), Cyprus", in Marotta, A.; Spallone, R., eds., FORTMED 2018. Proceedings of the International Conference on Modern Age Fortification of the Mediterranean Coast, Politecnico di Torino, Torino, vol. VIII, pp. 471-478. 
Camiz, A.; Griffo, M.; Baydur, S.; Fidan, F.T.; Khalil, S.I. (2017). "The round corner tower of Kyrenia's city walls (1211-1232)", in González Avilés, A.B., ed., FORTMED 2017. Defensive Architecture of the Mediterranean. XV to XVIII Centuries, Publicacions Universitat d'Alacant, Alacant, vol. IV, pp. 55-62.

Camiz, A.; Khalil, S.I.; Demir, S.C.; Nafa, H. (2016). "The Venetian defense of the Mediterranean: the Kyrenia Castle, Cyprus (1540-1544)", in Verdiani, G., ed., FORTMED 2016. Defensive architecture of the Mediterranean. XV to XVIII Centuries, DIDApress, Firenze, vol. III, pp. 371-378.

Dreghorn, W. (1977). A Guide to the Antiquities of Kyrenia, Halkin Sesi, Kyrenia.

Edbury, P.W. (1991). The Kingdom of Cyprus and the Crusades, 1191-1374, Cambridge University Press, Cambridge.

Enlart, C. (1899). L'art Gothique et la Renaissance en Chypre, Ernest Leroux Éditeur, Paris.

Gunnis, R. (1936). Historic Cyprus: A Guide to its Towns and Villages, Monasteries and Castles, Methuen, London.

Graziani, A.M., Lusignano, S.; Midgley, R. (1687). The History of the War of Cyprus. Written originally in Latin. With a new map of the island, J. Rawlins, London.

Hilton, J.R. (1936). Repair to Ancient Monuments, Report of the Department of Antiquities, Cyprus, p. 5.

Jeffery G. (1918). A description of the Monuments of Cyprus, William James Archer, Nicosia.

Lusignan, E. De. (1573). Chorografia et breve historia universale dell'isola de Cipro principiando al tempo di Noè per in sino al 1572, A. Benaccio, Bologna.

Mariti, G. (1909). Travels in the island of Cyprus, Cibham, C.D., trans., Cambridge University press, Cambridge.

Megaw, A.H.S. (1951). "Repair of ancient monuments 1937-1939”, in Report of the Department of Antiquities Cyprus, 1937-1939, p. 179.

Mol, E. (2012). Hidden Complexities of the Frankish Castle: Social Aspects of Space in the Configurational Architecture of Frankish Castles in the Holy Land, 1099-1291, Leiden University Press, Leiden.

Nicole, D. (2007). Crusader Castles in Cyprus, Greece and the Aegean 1191-1571, Osprey Publishing, London.

Novara, P. De. (1887). Le gestes des Chiprois: recueil de chroniques francaises ecrites en Orient au XIIIe \& XIVe siecles, J.G. Flick, Geneve.

Perbellini, G. (1973). "Le fortificazioni di Cipro dal X al XVI secolo", Castellum. Rivista dell'Istituto italiano dei castelli, 17, pp. 7-58.

Petre, J. (2012). Crusader castles of Cyprus: the fortifications of Cyprus under the Lusignans, 1191-1489, Cyprus Research Centre, Nicosia.

Yilmaz, I. (2010). The Kitab-1 Bahriye (Book of Navigation) of Piri Reis, The Cartographic Journal, The World of Mapping, 47(3), pp. 278-283. 
